\title{
Emotional Stress Consequences in the Development of Type 2 Diabetes Mellitus and Solutions
}

\author{
Review Article
}

\section{Charu Bansal1*, Rachna Jain², Umesh Shukla², Smita Paul ${ }^{4}$}

1. Professor (PhD scholar), Department of Swasthavritta \& Yoga, 3. Principal \& Head Department of Panchakarma,

Pt. Khushilal Sharma Govt. Ayurveda College \& Institution, Bhopal M.P.

2. Professor \& HOD Department of Swasthavritta \& Yoga,

4. Professor \& HOD Department of Roga Nidan Evam Vikriti Vigyan, Rani Dullaiya Memorial Ayurveda P.G. College \& Hospital, Bhopal M.P.

\begin{abstract}
India is recognized as diabetic capital of the world now and among all chronic diseases increased prevalence of Type 2 Diabetes mellitus has been recognized globally. Though various modifiable risk factors are identified for the development of type 2 diabetes mellitus such as prediabetes, overweight, obesity, poor diet, smoking, physical inactivity and given importance in the management of disease. But among all stress and anxiety has not been getting proper importance in development and management of Type 2 diabetes. Though number of studies have been identified stress as risk factor for type 2 diabetes. Thus, the present write up is aimed to review the effect of different emotional stressor as risk in the development and uncontrolled hyperglycemia in type 2 diabetes mellitus patients with effective solutions. Material and Methods: This review is based on data collected from classical Ayurvedic literature, and published research works in various journals. Observations and Results: cited based on research reviews to find out risk odds of different emotional stressor and type 2 diabetes with solutions based on Ayurveda and Yoga principles such as role of Raga therapy, Yogasan, Pranayama (breathing technique), Panchakarma procedures and use of Medhya Rasayana (nootropic) drugs. Conclusion: Counselling would be one of the best strategy to create awareness among healthy individual and type 2 diabetic to opt healthy behaviour to manage emotional stress and for the prevention and better control of type 2 diabetes mellitus. Thus, Present write up is an effort to provide attention on various emotional stressor as risk factor and also discuss the various healthy behavioural techniques to control emotional stress.
\end{abstract}

Key Words: Type 2 Diabetes mellitus, Stress, Diabetes risk factors, Emotional stress impact.

\section{Introduction}

Diabetes mellitus is a fastest growing serious global health problem that is prevalent in all ages. Its prevalence raised rapidly in low and middle income countries. In 2014 WHO estimated, 422 million people in the world had diabetes with prevalence of $8.5 \%$ among the adult population. In 2016 nearly 1.6 million deaths were reported by diabetes, in which almost half of deaths occurred before the age of 70 years.(1) Type 2 diabetes mellitus (T2DM) is the most common form of diabetes affecting nearly $95 \%$ of individuals, results from the body's ineffective use of Insulin.(2)

Number of clinical and experimental studies identified that various forms of stress especially emotional stress and any adverse life event can

\section{* Corresponding Author:}

\section{Charu Bansal}

Professor (PhD Scholar), Department of Swasthavritta, Pt. Khushilal Sharma Govt. Ayurveda College \& Institution, Bhopal.

Madhya Pradesh. - 462042 India.

Email Id: bansalcharu73@rediffmail.com contribute to the development of type 2 diabetes. Hormonal changes that occur during acute and chronic stress situations affect glucose homeostasis in both healthy people and diabetic patients and increased medical complications among those with type 2 diabetes mellitus.

\section{Material and Methods}

This review is structured on data assembled from Ayurvedic compendia, journals and researches related to stress anxiety and development of type 2 diabetes. The study also includes solution to overcome this situation. A meticulous understanding, co-relation with analysis has been carried out to highlight this issue.

\section{Impact of Chronic Stress on Health}

A recent WHO-led study estimates that depression and anxiety disorders cost the global economy US\$ 1 trillion each year in lost productivity. Chronic stress had been reported to worsens diabetes and lead to the depression and vies versa depression also increases the risk of diabetes. Anxiety is reported to impair the metabolic processes and increase diabetes 
Charu Bansal et.al., Emotional Stress Consequences in the Development of Type 2 Diabetes Mellitus and Solutions

complications.(3) So, timely assessment of psychological parameters in patients and management of chronic stress is highly essential in the prevention and management of type 2 diabetes.

Endocrinologist Hans Selye evaluate concept of 'stress' in 1930s. In 1950 Selye has been defined stress as 'the nonspecific response of the body to any demand.' During stressful situation body deal with "general adaptation syndrome" with three general stage to deal with stressor i.e. the alarm phase (Cannon's fight-or-flight), the resistance phase to the stress, and the exhaustion phase in presence of long stress (physical or emotional stress) which can cause serious health consequences like depression and start to dysfunction or shut down of body system. Signs of stress can be defined at cognitive, emotional, physical or behavioral level. Poor judgment, low self-esteem, poor concentration, and negative cognitions are cognitive signs of stress. Anxiety, excessive worrying, irritability, agitation, and feeling lonely or even isolated depressed mood are emotional signs. Body aches, nausea, dizziness, rapid heartbeat and chest pain are physical signs of stress. While, eating too much or not enough, sleeping too much or not enough, are behavioral symptoms of stress.

\section{Possible Ways of Stress to Develop Type 2 Diabetes}

Research studies observed that, emotional stress can increase the risk of initiation of type 2 diabetes by different pathways such as-

\section{Unhealthy Behavioural Mechanisms}

It has been evidenced that emotional stress mostly linked with unhealthy lifestyle behaviours, such as, inadequate eating behaviours (in quality and quantity of food), inadequate physical activity, smoking and alcohol abuse (Rod et al., 2009)(4) in future work as risk factors for the development of type 2 diabetes.

\section{Life Events or Sufferings and the Risk of Type 2 Diabetes}

Mooy et al. (2000) in cross-sectional study $(n=2,262)$ found that those were experienced significant life events during the past five years had 1.6-fold increased risk to have type 2 diabetes compared to those who had not experienced life events. Study also found positive association with the Waist-Hip-Ratio (WHR), which is an important risk factor for type 2 diabetes. (5) Goodwin and Stein (2004) used data from the National Comorbidity Survey $(\mathrm{n}=5,877)$ and reported, a history of childhood neglect was associated with a higher risk of diabetes (OR 2.2, 95\% CI 1.1-4.4) and this risk was higher among women (OR 4.6, 95\% CI 2.3-9.3), after adjustment for age, gender, race, marital status, income, and education. (6) Another study Raikkonen et al. (2007) middle-aged women those were having depressive symptoms, feeling frequently intensely angry, tensed or stressed, and very stressful life events were all associated with an increased risk to develop the metabolic syndrome during the 15 -year follow-up. (7)

\section{Physiological Mechanisms}

The long term activation of the hypothalamicpituitary-adrenal axis and the sympathetic nervous system due to depression and chronic stress reaction was noted which was linked with the development of abdominal obesity and further development of type 2 Diabetes (Vogelzangs et al., 2008).(8) Additionally, various experimental and clinical studies showed that chronic stress and depression can increase proinflammatory cytokines and glucocorticoids, specially cortisol hormone and make changes in behaviour (Leonard and Myint, 2009).(9) Pickup JC(2004), found Sleep disturbance and depression were linked with hypercytokinemia and activated innate immunity and also found that this cytokine- induced acute-phase response was closely linked with initiation of type 2 diabetes.(10)

\section{Observations and Results}

\section{Research Evidences of General Emotional Stress and} Risk of Type 2 Diabetes

Several prospective studies have experienced that general emotional stress associated as risk factor for the development of type 2 diabetes. Rod $\mathrm{NH}$ et al. 2009 , conduct a longitudinal study to determine the long-term effects of general emotional stress on changes in health behavior and cardiac risk profile in 7,066 men and women, found that stressed men but not women were more than two times risk to develop diabetes during follow-up $(2.4 ; 95 \%$ CI 1.2-4.6). It was also reported that highly stressed were nearly twice physically inactive $(1.9 ; 95 \%$ CI 1.4-2.6), and less likely to stop smoke and drinking during follow-up: all these factors are known to be associated with an increased risk for type 2 diabetes and could mediate the link between stress and onset of diabetes.(11)

Kato et al., in 10 year follow up Japanese community-based cohort study, included 55,826 subjects $(24,826$ men and 31,000 women) aged 40-69 years, reported risk of diabetes increased with an increased stress level, especially among men. The multivariate adjusted odds ratios for high stress compared with low stress were 1.36 (95\% CI 1.13-1.63) among men and 1.22 (95\% CI 0.98-1.51) among women (Kato et al., 2009).(12) Also, Toshihiro et al. (2008) among 128 male Japanese workers with impaired fasting glucose and/or impaired glucose tolerance reported Psychosocial factors were independent risk factors for the development of Type 2 diabetes in Japanese after a 3-year follow-up (HR 3.81, 95\% CI 1.09-13.4).(13)

Research Evidences of Depression, Anxiety and the Risk of Type 2 Diabetes

Meta-analysis based studies have been reported link between depression as risk for the onset of type 2 
diabetes. Knol et al. (2006) were reported that depression increases the risk for type 2 diabetes by $37 \%$.(14) Mezuk et al. (2008) in meta- analysis of 13 studies recorded that, the risk for incident diabetes was $60 \%$ higher in depressed participants, compared to nondepressed controls (RR 1.60, 95\% CI 1.37-1.88). (15) Engum (2007) large population-based study $(n=37,291)$ reported both anxiety and depression were associated with an increased risk for the development of type 2 diabetes at 10 years follow-up (OR 1.5, 95\% CI 1.3-1.8).(16)

\section{Research Evidences of Anger and Risk of Type 2 Diabetes}

Golden et al. (2005) have conducted a longitudinal cohort study of 11,615 non-diabetic adults aged 48-67 years, and reported anger temperament was significantly associated with onset of type 2 diabetes (HR 1.34, 95\% CI 1.1-1.6). Also, higher caloric intake and adiposity were potential mediators of this association.(17) Zhang et al. (2006) in 643 non- diabetic men with a mean age of 63 years, reported high aggression and stressed persons were more likely to have higher insulin resistance levels due to by the stress hormone norepinephrine.(18) This result is in line with earlier studies by Surwit et al.2002 (19) and Raikkonen et al. 2003.(20)

\section{Research Evidences of Distressed Sleep and the Risk of Type 2 Diabetes}

Poor sleep is one of the important indicator of emotional stress. Emotional stress can disturb normal sleep quality, initiation of sleep, and sleep duration. Cappuccio et al. (2010), conduct a systematic review and meta-analysis by including 10 studies found that short duration of sleep (less than 5 to 6 hours per night) increased the risk for type 2 diabetes (HR 1.3, 95\% CI 1.03-1.60). Difficulties in initiating sleep also increased the risk for the onset of type 2 diabetes (HR 1.6, 95\% CI 1.3-2.0). Even they reported that, long duration of sleep, more than 8-9 hours per night were also at increased risk for incident type 2 diabetes (HR 1.5 95\% CI 1.1-2.0). Difficulty in maintaining sleep was associated with an $84 \%$ higher risk to develop type 2 diabetes (HR 1.84, 95\% CI 1.4-2.4). (21)

\section{Research Evidences of Work Stress and the Risk of Type 2 Diabetes}

Kawakami et al., 1999, reported excessive overtime, has been associated with 4-fold higher risk of type 2 diabetes in Japanese men (independent of other risk factors) while, job strain was not significantly associated with incident of diabetes.(22) Norberg et al., 2006 , in a large $(n=33,336)$ population-based study reported tense working situation/ work stress was associated with onset of diabetes after, on average, 5 years, in women (OR $3.695 \%$ CI 1.0-13.3) but not in men (OR 1.1, 95\% CI 0.4-2.9),(23) in another study Melamed et al., 2006 reported chronic work stress as a risk factor for the development of type 2 diabetes (OR 1.8, 95\% CI 1.2-2.9).(24) While Heraclides et al., 2009 also reported similar findings.(25)

\section{Discussion}

Different kinds of long-term emotional stress had always been identified as increased risk of development of Type 2DM such as stressful life events, especially depression, general emotional stress, anxiety, anger/hostility, and sleeping problems. These events have been reported strong link with higher odds of increased risk of type 2 diabetes directly and indirectly by increasing risk of development metabolic syndrome and impaired fasting glucose. Normally, physiological changes occur due to stress are adaptive, compensatory, and self- limiting but in chronic stressful conditions these physiological changes become rather irreversible and pathological in nature.(26)

More than 400 years ago, English physician Thomas Willis were experienced significant and chronic life stresses were more prone for diabetes. Later, based on this hypothesis American psychiatrist Dr. W. Menninger, conduct study and found the existence of psychogenic diabetes and described it as "diabetic personality".(27) Depressed persons suffered from high emotional stress and had more risk of development of type $2 \mathrm{DM}$ and even type 2 diabetic patients have double risk for co-morbid depression.(28) Branis NM, et al (2015) reported, due to emotional chronic stress release of adrenergic and catecholamine hormones increases. Thus, the sympathetic hormone by enhancing fight or flight response in body plays a significant role in development of hyperglycaemia because these adrenergic hormones can stimulate glucose production and reduce the insulin level, therefore worsening the diabetic condition. (29) Various clinical and experimental evidence which have been already discussed in previous section supports an association between chronic stress and initiation of type 2 diabetes also association between stress hyperglycemia and increased morbidity and mortality in critically ill patients. Studies also supporting stress can influence the development of type 2 diabetes indirectly by promoting obesity and metabolic syndrome.

\section{Future Strategies to Control Emotional Stress}

To maintain mental health three kinds of therapies, Daivavyapashraya (spiritual therapy), Yuktivyapashraya (therapy based on reasoning, i.e. physical properties), and Satvavajaya (psychotherapy treatment by self-control) described in Ayurveda.

\section{Establishment of Counselling Clinics}

Counselling would be one of the best strategy to create awareness to opt healthy behaviour such as healthy eating, physically active lifestyle, meditation, Music or Raga therapy, Mantra chanting (verbal or silent repetition of sacred sound formulas), Yogasan (postural yoga) Pranayama (breathing technique), Preventive Panchakarma and use of Medhya Rasayana is needed. It is also important to educate them to adopt peaceful, positive and spiritual thinking and trained in various techniques which can help to withdrawal their mind from harmful objects. Because life which could 
Charu Bansal et.al., Emotional Stress Consequences in the Development of Type 2 Diabetes Mellitus and Solutions

prevent and control stress can directly and indirectly prevent and control type 2 diabetes.

\section{Role of Music Therapy}

Presently various conventional pharmaceutical preparations are used to treat stress, anxiety but, there is need to a paradigm shift from the present dominant and often exclusive use of chemotherapy to Music therapy. Thus, to encourage the general population towards involvement in Raga therapy or Music therapy could be the best technique to prevent from stress and anxiety because ragas by inducing electromagnetic change in the body improve various psychological ailments by relaxing body and mind due to greater effect of alpha waves of the brain and by favourable hormonal changes and by improving sleep quality and sleep. As various clinical studies indicating that music therapy can reduce Stress and anxiety by modifying the autonomic nervous system activity and increased the parasympathetic nervous system activity in young adults (Peng SM et. al 2009, Balaji Deekshitulu P.V 2015). (30, 31)

\section{Role of Preventive Panchakarma Procedures}

Panchkarma Procedures especially designed to eliminate body toxins, facilitate adequate nutrition to each Dhatus and balance equilibrium in doshas thus can maintain mental health. Shirodhara and Nasya could be advised for prevention and control of stress and anxiety. Brimhana Nasya due to its nourishing strengthening properties, had been directly act on head, and provided nourishment to neurons, improving sleep quality. Researches also reported potential efficacy of Nasya procedure in enhancement of quality of sleep and reduction in stress and anxiety.(32) Shirodhara procedure due to penetrating pressure of oil stimulate nerve endings and Marmas (vital areas of the body) increases circulation and also enhances action of neurotransmitters like Serotonin, Nor-epinephrine and metabolism of Dopamine and catacholamines thus reducing stress and provides natural tranquilizing effect. Several studies reported its anti-anxiety, antihypertensive and sleep inducing effects cited in Table No. 1 with their mode of action.

Table No. 1: Shirodhara Procedure and their Role in Psychological Problems

\section{Reference Mode of Action}

Uebaba et Reduce the sympathetic tone thereby al., 2008; decreasing the cardiac activity and $\mathrm{Xu}$ et al., increasing $\alpha$ and $\theta$ wave activity in 2008. (33, brain

34)

Uebaba et Reduce catecholamine and an increased al., 2005 serotonin reuptake is proposed as one

Vinjamury Relieve insomnia,

SP, et al.

$2014(36)$

\section{Role of Medhya Rasayanas}

In Ayurveda number of Medhya Rasayanas (group of 04 medicinal plants) are mentioned to maintain normal mental health, and for inhibition and dealing mental disorders those can be used singly or in combinations. They are Mandukaparni (Centella asiatica Linn.), Yastimadhu (Glycirrhiza glabra Linn.), Guduchi (Tinospora cordifolia (Wild) Miers.) and Shankhapushpi (Convolvulus pleuricaulis Chois). Some other drugs used with same aim can Jatamamsi (Nardostachys jatamansi D. Don), Jyothishmati (Celastrus paniculatus Willd.), Aindri (Bacopa monnieri L. Pennell), Kushmanda (Benincasa hispida Thunb. Cogn.), and Vacha (Acorus calamus Linn.) can also advised to prevent and manage stress and anxiety in type 2 diabetes patients and healthy person to cited in Table No. 2 with their mode of action.

Table No. 2: Ayurvedic Herbs and their Role in Psychological Problems

\begin{tabular}{|c|c|c|c|}
\hline Botanical Name & Nature of study & Mode of Action & Reference \\
\hline $\begin{array}{l}\text { Centella asiatica } \\
\text { Linn. }\end{array}$ & Experimental study & $\begin{array}{l}\text { Enhances learning and memory in } \\
\text { mice }\end{array}$ & $\begin{array}{l}\text { Rao SB, Chetana M, Uma } \\
\text { Devi P. } 2005 \text { (37) }\end{array}$ \\
\hline $\begin{array}{l}\text { Centella asiatica } \\
\text { Linn. }\end{array}$ & Experimental study & $\begin{array}{l}\text { Attenuates glutamate-induced } \\
\text { cognitive deficits in mice and } \\
\text { apoptosis in SH-SY5Y cells. }\end{array}$ & $\begin{array}{l}\text { Xu MF, Xiong YY, Liu } \\
\text { JK,et al. } 2012(38)\end{array}$ \\
\hline $\begin{array}{l}\text { Centella asiatica } \\
\text { Linn. }\end{array}$ & Experimental study & $\begin{array}{l}\text { Antioxidant and DNA Damage } \\
\text { Preventive Properties of }\end{array}$ & $\begin{array}{l}\text { Anand T, Naika M, et al. } \\
2010 \text { (39) }\end{array}$ \\
\hline $\begin{array}{l}\text { Glycyrrhiza } \\
\text { glabra Linn. }\end{array}$ & Experimental study & $\begin{array}{l}\text { Antidepressant-like activity in } \\
\text { mouse models of immobility tests. }\end{array}$ & $\begin{array}{l}\text { Dhingra D, Sharma A. } \\
2006(40)\end{array}$ \\
\hline $\begin{array}{l}\text { Glycyrrhiza } \\
\text { glabra Linn. }\end{array}$ & Experimental study & $\begin{array}{l}\text { Root extract showed Cerebro- } \\
\text { protective effect of on Hypoxic rats }\end{array}$ & $\begin{array}{l}\text { Muralidharan P, } \\
\text { Balamurugan G, et al. } 2009 \\
\text { (41) }\end{array}$ \\
\hline $\begin{array}{l}\text { Glycyrrhiza } \\
\text { glabra Linn. }\end{array}$ & Experimental study & $\begin{array}{l}\text { The roots and rhizomes efficient } \\
\text { brain tonic as increases the } \\
\text { circulation into the CNS system and } \\
\text { balance the sugar levels in the blood. }\end{array}$ & $\begin{array}{l}\text { Rathee P, Chaudhary H, et } \\
\text { al. } 2008 \text { (42) }\end{array}$ \\
\hline $\begin{array}{l}\text { Convolvulus } \\
\text { pleuricaulis } \\
\text { Chois }\end{array}$ & Experimental study & Showed antidepressant-like activity & $\begin{array}{l}\text { Dhingra D, Valecha R. } \\
2007 \text { (43) }\end{array}$ \\
\hline
\end{tabular}


International Journal of Ayurvedic Medicine, Vol 12 (1), 7-13

\begin{tabular}{|l|l|l|l|}
\hline $\begin{array}{l}\text { Convolvulus } \\
\text { pleuricaulis } \\
\text { Chois }\end{array}$ & Experimental study & $\begin{array}{l}\text { Neuroprotective role on aluminium } \\
\text { induced neurotoxicity in rat brain }\end{array}$ & $\begin{array}{l}\text { Bihaqi SW, Sharma M, et } \\
\text { al. 2009. (44) }\end{array}$ \\
$\begin{array}{l}\text { Tinospora } \\
\text { cordifolia } \text { (Wild) } \\
\text { Miers. }\end{array}$ & Double-Blind RCT, & $\begin{array}{l}\text { Learning and Memory in Healthy } \\
\text { Volunteers }\end{array}$ & $\begin{array}{l}\text { Bairy KL, Rao Y, 2010. } \\
\text { (45) }\end{array}$ \\
$\begin{array}{l}\text { Tinospora } \\
\text { cordifolia } \text { (Wild) } \\
\text { Miers. }\end{array}$ & Experimental study & $\begin{array}{l}\text { Learning and Memory in normal and } \\
\text { memory deficit rats }\end{array}$ & $\begin{array}{l}\text { Agarwal A, Malini S,et al. } \\
\text { 2002. (46) }\end{array}$ \\
\hline $\begin{array}{l}\text { Tinospora } \\
\text { cordifolia } \text { (Wild) } \\
\text { Miers. }\end{array}$ & Experimental study & $\begin{array}{l}\text { Antioxidant action of root extract in } \\
\text { alloxan diabetic rats }\end{array}$ & $\begin{array}{l}\text { Stanely M, Prince P, et al. } \\
\text { 2001. (47) }\end{array}$ \\
\hline $\begin{array}{l}\text { Bacopa monnieri } \\
\text { L. Pennell }\end{array}$ & Experimental study & $\begin{array}{l}\text { Antioxidant effect of bacosides } \\
\text { (triternoid saponin isolated from } \\
\text { Bacopa monniera L.) against } \\
\text { chronic toxin induced oxidative } \\
\text { damage in rat brain }\end{array}$ & $\begin{array}{l}\text { Anbarasi K, Vani G, et al. } \\
\text { 2006. (48) }\end{array}$ \\
\hline $\begin{array}{l}\text { Nardostachys } \\
\text { jatamansi D. } \\
\text { Don }\end{array}$ & Experimental study & $\begin{array}{l}\text { Extract shown significant inhibition } \\
\text { of benzoyl peroxide-induced } \\
\text { cutaneous oxidative stress, toxicity } \\
\text { in mice }\end{array}$ & $\begin{array}{l}\text { Ali A, Dua Y, Siddiqui AW, } \\
\text { et al. 2005. (49) }\end{array}$ \\
\hline
\end{tabular}

\section{Challenges}

Challenges are big, because in India the concept of counselling clinic is not easily accepted in general population and most of them are not aware about the need to lead spiritually and emotionally healthy lifestyle for the prevention and maintenance of type 2 diabetes mellitus.

\section{Conclusion}

Emotional stress is an important contributor to develop various lifestyle diseases in humans especially type 2 diabetes. A significant association between depression and incidence of type 2 diabetes. Hormonal changes that occur during acute and chronic stress events directly affect glucose homeostasis in both healthy people and in diabetic patients. Thus need to adopt rigorous strategies and counselling clinics to modified healthy and type 2 diabetic patient's stressed and anxiety behaviours and maintain the proper function of neurotransmitters and help to relaxed them. Furthermore, outreach camps in between large population would be required to create general awareness in common persons about the usefulness to opt healthy lifestyle which could help to make them spiritually and emotionally strong and can prevent to healthy individual from initiation of type 2 diabetes mellitus and to effectively control in blood sugar level in diabetic patients.

\section{References}

1. Global Report on Diabetes- World Health Organization. http://www.apps.who.int> iris , bitstream > 9789241565257_eng. 7April, 2016. Last accessed on 18 Jan 2021,10 am.

2. Centers for Disease Control and Prevention. Diabetes report card 2012. Atlanta, GA: Centers for Disease Control and Prevention, US Department of Health and Human Services, 2012. Last accessed on
18 Jan 2021,10 am. Available from: www.cdc.gov/ DIABETES/pubs/pdf/DiabetesReportCard.pdf

3. Bickett A, Tapp H. Anxiety and diabetes: Innovative approaches to management in primary care. Exp Biol Med (Maywood). 2016[cited 2021 Jan 20]; $241: 1724-31$ Available from: pubmed.ncbi.nlm.nih.gov/27390262

4. Rod NH, Grønbaek M, Schnohr P, Prescott E, Kristensen TS. Perceived stress as a risk factor for changes in health behaviour and cardiac risk profile: a longitudinal study. J Intern Med. 2009[cited 2021 Jan 20]; 266(5):467-475 Available from: www.researchgate.net/publication/ $26333730 \ldots$

5. Mooy JM, De Vries H, Grootenhuis PA, Bouter LM, Heine RJ. Major stressful life events in relation to prevalence of undetected type 2 diabetes. The Hoorn Study. Diabetes Care. 2000[cited 2021 Jan $20]$; 23:197-201 Available from: care.diabetesjournals.org/content/33/2/378

6. Goodwin RD, Stein MB. Association between childhood trauma and physical disorders among adults in the United States. Psychol Med. 2004[cited 2021 Jan 20]; 34:509-520 Available from: pubmed.ncbi.nlm.nih.gov/15259836

7. Raikkonen K, Matthews KA, Kuller LH. Depressive symptoms and stressful life events predict metabolic syndrome among middle-aged women. Diabetes Care. 2007[cited 2021 Jan 20]; 30:872-77 Available from: www.ncbi.nlm.nih.gov/ pubmed/17392548

8. Vogelzangs N, Kritchevsky SB, Beekman AT, et al. Depressive symptoms and change in abdominal obesity in older persons. Arch Gen Psychiatry. 2008[cited 2021 Jan 20]; 65:1386-93 Available from: www.academia.edu/14416841/ Depressive_Symptoms.

9. Le on ard B E, Myint A. The psychoneuroimmunology of depression. Hum Psychopharmaco 24(3):165-175, 2009. McEwen 
Charu Bansal et.al., Emotional Stress Consequences in the Development of Type 2 Diabetes Mellitus and Solutions

BS. Stress, adaptation, and disease. Allostasis and allostatic load. Ann NY Acad Sci. 1998[cited 2021 Jan 20]; 840:33-44 Available from: link.springer.com/chapter/10.1007/978-3-319...

10. Pickup JC. Inflammation and activated innate immunity in the pathogenesis of type 2 diabetes. Diabetes Care. 2004[cited 2021 Jan 20]; $27(3): 813-23$ Available from: care.diabetesjournals.org/content/27/3/813

11. Rod NH, Grønbaek M, Schnohr P, Prescott E, Kristensen TS. Perceived stress as a risk factor for changes in health behaviour and cardiac risk profile: a longitudinal study. J Intern Med. 2009[cited 2021 Jan 20]; 266(5): 467-475 Available from: www.researchgate.net/publication/ $26333730 \ldots$

12. Kato M, Noda M, Inoue M, Kadowaki T, Tsugane S; JPHC Study Group. Psychological factors, coffee and risk of diabetes mellitus among middle-aged Japanese: a population-based prospective study in the JPHC study cohort. Endocr J. 2009[cited 2021 Jan 20]; 56(3):459-468 Available from: www.jstage.jst.go.jp/article/endocrj/56/3/56_K09...

13. Toshihiro M, Saito K, Takikawa S, Takebe N, Onoda T, Satoh J. Psychosocial factors are independent risk factors for the development of Type 2 diabetes in Japanese workers with impaired fasting glucose and/or impaired glucose tolerance. Diabet Med. 2008[cited 2021 Jan 20]; 25:1211-17 Available from: pubmed.ncbi.nlm.nih.gov/ 19046200

14. Knol M, Twisk J, Beekman A, Heine R, Snoek F, Pouwer F. Depression as a risk factor for the onset of type 2 diabetes: a meta-analysis. Diabetologia. 2006[cited 2021 Jan 20]; 49:837-845 Available from: pubmed.ncbi.nlm.nih.gov/16520921

15. Mezuk B, Eaton WW, Albrecht S, Golden SH. Depression and type 2 diabetes over the lifespan. Diabetes Care. 2008[cited 2021 Jan 20]; $31: 2383-2390$ Available from: pubmed.ncbi.nlm.nih.gov/19033418

16. Engum A. The role of depression and anxiety in onset of diabetes in a large population-based study. J Psychosom Res. 2007[cited 2021 Jan 20]; 62:31-38 Available from: www.sciencedirect.com/ science/article/pii/S...

17. Golden SH, Williams JE, Ford DE, Yeh H-C, PatonSanford C, Javier-Nieto F, Brancati FL. Anger temperament is modestly associated with the risk of type 2 diabetes mellitus: The atherosclerosis risk in community study. Psycho neuroendocrinology. 2006[cited 2021 Jan 20]; 31: 325-32 Available from: www.researchgate.net/publication/ 23164893 How...

18. Zhang J, Niaura R, Dyer JR, Shen BJ, et al. Hostility and urine norepinephrine interact to predict insulin resistance: the VA normative aging study. Psychosom Med. 2006[cited 2021 Jan $20] ; 68: 718-726$ Available from: www.ncbi.nlm.nih.gov/pmc/articles/PMC3642777

19. Surwit RS, Williams RB, Siegler IC, Lane JD, Helms M, Applegate KL, Zucker N, Feinglos MN,
McCaskill CM, Barefoot JC. Hostility, race, and glucose metabolism in nondiabetic individuals. Diabetes Care. 2002[cited 2021 Jan 20];25:835-839 Available from: www.ncbi.nlm.nih.gov/pubmed/ 11978677

20. Raikkonen K, Matthews KA, Salomon K. Hostility predicts metabolic syndrome risk factors in children and adolescents. Health Psychol. 2003[cited 2021 Jan 20]; 22:279-286 Available from: www.researchgate.net/publication/10722781...

21. Cappuccio FP, D'Elia LD, Strazzullo P, Miller MA. Quantity and quality of sleep and incidence of type 2 diabetes: a systematic review and meta-analysis. Diabetes Care. 2010[cited 2021 Jan 20]; 33:414-420 Available from: pubmed.ncbi.nlm.nih.gov/19910503

22. Kawakami N, Araki S, Takatsuka N, Shimizu H, Ishibashi H. Overtime, psychosocial work conditions, and occurrence of non-insulin dependent diabetes mellitus in Japanes men. J Epidemiol Community Health. 1999[cited 2021 Jan 20]; 53:359-363 Available from: jech.bmj.com/ content/jech/53/6/359.full.pdf

23. Norberg N, Stenlund H, Lindahl B, Andersson C, Eriksson JW, Weinehall. Work stress and low emotional support is associated with increased risk of future type 2 diabetes in women. Diabetes Res Clin Pract. 2007[cited 2021 Jan 20]; 76:368-377 Available from: care.diabetesjournals.org/content/ $32 / 12 / 2230$

24. Melamed S, Shirom A, Toker S, Shapira I. Burnout and risk of type 2 diabetes: a prospective study of apparently healthy employed persons. Psychosom Med. 2006[cited 2021 Jan 20]; 68:863-69 Available from: pubmed.ncbi.nlm.nih.gov/17132837

25. Heraclides A, Chandola T, Witte DR, Brunner EJ. Psychosocial stress at work doubles the risk of type 2 diabetes in middle-aged women. Diabetes Care. 2009[cited 2021 Jan 20]; 32: 2230-2235 Available from: www.ncbi.nlm.nih.gov/pubmed/? term=Psychosocial...

26. Makara GB. Mechanism by which stressful stimuli activate the pituitary adrenalsystem. Fed Proc 1985[cited 2021 Jan 20]; 44:149-53 Available from: www.ncbi.nlm.nih.gov/pubmed/2981736

27. Menninger WC. Psychological factors in etiology of diabetes. J Nerv Ment Dis.1935; 81:1-13 Available from: jamanetwork.com/journals/jama/fullarticle/ 666321

28. Kokoszka A, Pouwer F, Jodko A, Radzio R, et al. Serious diabetes-specific emotional problems in patients with type 2 diabetes who have different levels of comorbid depression: a Polish study from the European Depression in Diabetes (EDID) Research Consortium. Eur Psychiatry. 2009; 24(7): 425-430 Available from: www.cambridge.org/core/ journals/european.

29. Branis NM, Wittlin SD: Amphetamine-like analogues in diabetes: speeding towards ketogenesis. Case Rep Endocrinol. 2015[cited 2021 Jan 20]; 2015:1-4. 10.1155/2015/917869 Available 
from: www.ncbi.nlm.nih.gov/pubmed/? term=amfepramone

30. Peng SM, Koo M, Yu ZR. Effects of music and essential oil inhalation on cardiac autonomic balance in healthy individuals. Journal of alternative and complementary medicine (New York). 2009[cited 2021 Jan 20]; 15(1):53-7 Available from: www.ncbi.nlm.nih.gov/pubmed/ 19769477

31. Balaji Deekshitulu P.V. Role of mantras in mental health. International J of Humanities and Social Sci Studies. 2015; 6 (1): 34-39 Available from: escipub.com/ijnr-2017-04-0801

32. Asutkar S, Bende Y, Sharma VH, Jadhao VP, Asutkar VG, Gulhane C. Nasya karma (Intranasal Therapy); An alternative route of drug administration into the brain. Int $\mathrm{J}$ Ayu Pharm Chem 2015[cited 2021 Jan 20]; 4:77-90 Available from: www.ijapc.com/volume4-second-issue/77-89.pdf

33. Uebaba K, Xu FH, Ogawa H, Tatsuse T, Wang BH, $\mathrm{Hisajima}$ T, Venkatraman S. Psychoneuroimmunologic effects of Ayurvedic oildripping treatment. J Altern Complement Med. 2008; 14:1189-1198 Available from: www.researchgate.net/publication/237060922...

34. Xu F, Uebaba K, Ogawa H, Tatsuse T, Wang BH, Hisajima T, Venkatraman S. Pharmaco-physiopsychologic effect of Ayurvedic oil-dripping treatment using an essential oil from Lavendula angustifolia. J 2008[cited 2021 Jan 20];14: 947-956 Available from: www. aromaticscience.com/ pharmaco-physio-psychologic..

35. Uebaba K, Xu FH, Tagawa M, Asakura R, et al. Using a healing robot for the scientific study of shirodhara. Altered states of consciousness and decreased anxiety through Indian dripping oil treatments. IEEE Eng Med Biol Mag. 2005[cited 2021 Jan 20]; 24: 69- 78 Available from: www.researchgate.net/publication/ 23758916_Psych...

36. Vinjamury SP, Vinjamury $M$, der Martirosian $C$, Miller J. Ayurvedic therapy (shirodhara) for insomnia: a case series. Glob Adv Health Med. 2014[cited 2021 Jan 20]; 3:75-80 Available from: www.researchgate.net/publication/315629145...

37. Rao SB, Chetana M, Uma Devi P. Centella asiatica treatment during postnatal period enhances learning and memory in mice. Physiol Behav. 2005[cited 2021 Jan 20]; 86: 449-457 Available from: www.ncbi.nlm.nih.gov/pubmed/16214185

38. Xu MF, Xiong YY, Liu JK, Qian JJ, Zhu L, et al. Asiatic acid, a pentacyclic triterpene in Centella asiatica, attenuates glutamate-induced cognitive deficits in mice and apoptosis in SH-SY5Y cells. Acta Pharmacol Sin. 2012[cited 2021 Jan 20]; 33: 578-587 Available from: www.spandidospublications.com/10.3892/ol.2013.1597

39. Anand T, Naika M, Kumar PG, Khanum F. Antioxidant and DNA Damage Preventive
Properties of Centella asiatica (L) Urb. Phcog J. 2010[cited 2021 Jan 20]; 2: 53-8 Available from: www.phcogfirst.com/article/380

40. Dhingra D, Sharma A. Antidepressant-like activity of Glycyrrhiza glabra L. in mouse models of immobility tests. Prog Neuropsychopharmacol Biol Psychiatry. 2006[cited 2021 Jan 20]; 30: 449-454 Available from: pubmed.ncbi.nlm.nih.gov/ 16443316

41. Muralidharan P, Balamurugan G, Venu Babu. Cerebroprotective effect of Glycyrrhiza glabra Linn. root extract on Hypoxic rats. Bangladesh J Pharmacol. 2009[cited 2021 Jan 20]; 4:60-4 Available from: www. researchgate.net/publication/ 26541439.

42. Rathee P, Chaudhary H, Rathee S, Rathee D. Natural memory boosters. Phcog Rev. 2008[cited 2021 Jan 20]; 2:249-56 Available from: www.researchgate.net/publication/233894039...

43. Dhingra D, Valecha R. Evaluation of the antidepressant-like activity of Convolvulus pluricaulis choisy in the mouse forced swim and tail suspension tests. Med Sci Monit. 2007[cited 2021 Jan 20]; 13: BR155-161 Available from: www.ncbi.nlm.nih.gov/pubmed/17599020

44. Bihaqi SW, Sharma M, Singh AP, Tiwari M. Neuroprotective role of Convolvulus pluricaulis on aluminium induced neurotoxicity in rat brain. J Ethnopharmacol. 2009[cited 2021 Jan 20]; 124: 409-415 Available from: www.ncbi.nlm.nih.gov/ pubmed/19505562

45. Bairy KL, Rao Y, Kumar KB. Efficacy of Tinospora cordifolia on Learning and Memory in Healthy Volunteers: A Double-Blind, Randomized, Placebo Controlled Study. Iranian Journal of Pharmacology and Therapeutics. 2004 [cited 2021 Jan 20]; 3: 5760 Available from: scholar.google.com/citations? user $=$ CEiR-sMAAAAJ\&hl=en

46. Agarwal A, Malini S, Bairy KL, Rao MS. Effect of Tinospora cordifolia on Learning and Memory in normal and memory deficit rats. Indian $\mathrm{J}$ Pharmacol. 2002; 34: 339-49

47. Stanely M, Prince P, Menon VP. Antioxidant action of Tinospora cordifolia root extract in alloxan diabetic rats. Phytother Res. 2001[cited 2021 Jan 20 ]; 15: 213-8 Available from: www.researchgate.net/publication/317434110...

48. Anbarasi K, Vani G, Balakrishna K, Devi CS. Effect of Bacoside $\mathrm{A}$ on Brain antioxidant status in cigarette smoke exposed rats. Life Sci. 2006[cited 2021 Jan 20]; 78:1378 Available from: www.ncbi.nlm.nih.gov/pubmed/16226278

49. Ali A, Dua Y, Siddiqui AW, Sultana S, Rafiullah MR. Inhibition of benzoyl peroxide-induced cutaneous oxidative stress, toxicity and ear edema in mice by Nardostachys Jatamansi. Pharm Biol. 2005[cited 2021 Jan 20]; 43:533-9 Available from: www.researchgate.net/publication/232053983... 